\title{
PSEUDOMONAS AERUGINOSA IN RESPIRATORY ILLNESS: ENDOGENOUS OR EXOGENOUS?
}

\author{
HARRIET B. H. SMTTH, M.SC., DIP.BACT.(TOR.), AND \\ Peter G. TUfFNeLL, M.R.C.S., L.R.C.P., M.R.C.PATH."
}

Pseudomonas aeruginosa is isolated frequently from the respiratory secretions of patients at the Toronto General Hospital who have serious respiratory illnesses which have necessitated intubation and inhalation therapy. It was the specific purpose of this investigation to determine if cross-infection (exogenous nosocomial) acquired in hospital contributed to the high incidence of this organism. In this study "infection" was used synonymously with "colonization," since no criteria were used to distinguish between the two possible states.

Pyocine typing was used to differentiate the strains isolated. It is a satisfactory tool for epidemiological studies ${ }^{1}$ and is simpler for this purpose than either phagetyping or serotyping. ${ }^{2}$

A satisfactory sampling of strains from the hospital as a whole was undertaken to determine the normal distribution of types from the general hospital population. In particular, studies were made of the distribution of types from the two respiratory wards, one of which was an intensive care unit (respiratory failure unit). Thus the frequency of pyocine types from the respiratory wards could be compared with that of the general patient population to determine if crossinfection existed as a problem. In cross-infection, deviation from the expected frequency would occur with a significant increase in the frequency of one or more types. No attempt was made to survey the environment for reservoirs of infection nor to detect carrier sites in the patients before gross colonization became apparent.

\section{Materials and Methods}

\section{Indicator strains}

To date there is no international set of indicator strains nor standardized method of performing pyocine typing. Some workers ${ }^{2}$ have used the twelve indicator strains of the Colindale Laboratories, nine of which were the original strains of Darrell and Wahba. ${ }^{1}$ However, in the laboratory of the Toronto General Hospital the eight strains and five subtyping (E) strains of Gillies ${ }^{3}$ and Govan ${ }^{4}$ were used. These strains were obtained from the Department of Microbiology, Sunnybrook Hospital, Toronto, where they had been maintained in stock since they were obtained from Gillies and Govan several years ago.

\section{Producer strains}

Producer or "patient" strains were isolated and identified as Pseudomonas aeruginosa in the routine diagnostic laboratory. They were submitted for pyocine

-Department of Microbiology, Toronto General Hospital. 
typing either on the original isolation medium or on the antibiotic sensitivity plate. Repeated isolations of the same type of specimen from the same patient were not included in this study for statistical purposes unless the pyocine type differed.

\section{Maintenance of strains}

Strains were maintained on nutrient agar slants at $4-10^{\circ} \mathrm{c}$. It was found that indicator strains needed to be subcultured every three weeks to ensure viability.

\section{Procedure}

The method of Govan and Gillies ${ }^{4}$ was followed. The producer strain was grown in trypticase soy broth (TSB) ${ }^{\circ}$ for four to six hours at $37^{\circ} \mathrm{C}$. Then the strains were streaked diametrically across a plate of trypticase soy blood agar (TSBA) in glass plates using a sterile cotton-tipped applicator, giving a streak approximately $1 \mathrm{~cm}$ wide. This procedure was undertaken just prior to 5 PM on day 1 . The TSBA plates were then incubated at $32^{\circ} \mathrm{C}$ until 9 AM of day 2 . The producer strain growth was removed from each TSBA plate by scraping with a glass slide and then with cotton-tipped applicators. Care was taken to not bruise the agar. The plates were exposed to chloroform by placing 3 to $5 \mathrm{ml}$ in the lid of each petri dish while it was inverted with the lid on the bottom side. The residual chloroform was removed after 15 minutes and the plates were allowed to ventilate for 15 minutes by leaving them ajar. Then the plates were stored in the refrigerator until the indicator strains were ready for use.

As early as convenient on day 2 the indicator strains were inoculated into $2 \mathrm{ml}$ TSB and incubated for four hours to ensure log phase growth. Then these strains were streaked in consecutive order onto the TSBA plates at right angles to the line of growth of the producer strain. The plates were incubated at $37^{\circ} \mathrm{c}$ until next morning. Inhibition of the indicator strains was noted.

The pyocine type was determined from the pattern of inhibition observed. The 36 types of Gillies and Govan ${ }^{3}$ were listed as the first 36 types of the system. Patterns in addition to these 36 were observed and numbered thereafter. Subtyping of Type 1 was carried out in a like manner using the five $\mathrm{E}$ strains as indicator strains.

\section{Recording results}

Each patient strain was assigned a punch card and the appropriate data noted: patient's name, location in hospital, microbiology specimen number, type of specimen, results of typing with the eight indicator strains and, if Type 1, results of the subtyping. Information was readily retrieved by the "knitting needle" technique.

\section{RESULTS}

The results of pyocine typing of patient strains of Pseudomonas aeruginosa for a six-month period from areas in the hospital other than the respiratory failure unit and Ward A South are given in Table I. Of the 206 patient strains submitted

-Baltimore Biological Laboratories, Division of Bioquest, Becton, Dickinson \& Co., Canada, Ltd., 264 South Sheridan Way, Clarkson, Ontario. 
TABLE I

Results of Pyocine Typing of Patient Strains of Pseudomonas aeruginosa for a SIX-MONTh PERIOD*

\begin{tabular}{|c|c|c|c|c|c|c|}
\hline \multirow{2}{*}{$\begin{array}{c}\text { Source of } \\
\text { patient strains }\end{array}$} & \multicolumn{3}{|c|}{ Pyocine type (\%) } & \multirow{2}{*}{$\begin{array}{c}\text { Other } \\
\text { types } \\
(\%)\end{array}$} & \multirow{2}{*}{$\begin{array}{c}\text { Non- } \\
\text { typable } \\
(\%)\end{array}$} & \multirow{2}{*}{$\begin{array}{l}\text { Total } \\
(\%)\end{array}$} \\
\hline & 1 & 10 & 3 & & & \\
\hline \multirow{2}{*}{$\begin{array}{l}\text { Hospital population } \\
\text { other than listed } \\
\text { below } \\
\text { Respiratory failure } \\
\text { unit } \\
\text { A South }\end{array}$} & $28.6(59)$ & $15.5(32)$ & $8.7(18)$ & $35.0(72)$ & $12.1(25)$ & $100(206)$ \\
\hline & $\begin{array}{l}26.5(13) \\
34.8(8)\end{array}$ & $\begin{array}{l}20.4(10) \\
39.1^{(9)}\end{array}$ & $\begin{array}{ll}6.1 & (3) \\
0 & (0)\end{array}$ & $\begin{array}{l}36.7(18) \\
26.1(6)\end{array}$ & $\begin{array}{cc}10.2 & (5) \\
0 & (0)\end{array}$ & $\begin{array}{l}100(49) \\
100(23)\end{array}$ \\
\hline
\end{tabular}

When a particular pyocine type was isolated from various kinds of specimens from the same patient, the strain was considered a "patient strain" and for statistical purposes in this table counted only once. Numbers of patient strains are shown in parentheses.

to the typing procedure, 12.1 per cent were non-typable (did not produce pyocines which would inhibit any of the eight indicator strains). Approximately half (52.8 per cent) of the typable strains were of three types, 1,10 , and 3 in descending order, while the remaining 35 per cent of the strains were distributed among the other types.

Table I also shows the results of pyocine typing of patient strains of $P$ seudomonas aeruginosa for the same six-month period from the respiratory failure unit and Ward $\mathbf{A}$ South. Statistically there is not any significant difference between the distribution of the types from these wards and the expected distribution based on the hospital population. Although the occurrence of 39.1 per cent of Type 10 from Ward A South seems large when compared with 15.5 per cent from the "population," the small size of the sample from this ward contributes to the statistical insignificance of this difference.

Table II shows the distribution of patient strains of the subtypes of pyocine Type $I$ in the respiratory failure unit and Ward $A$ South as compared with the distribution in other areas of the hospital. In order to increase the number of strains used to determine the "population" distribution ("other areas"), 28 more strains of Type 1, isolated after the termination of the original six-month period, were subtyped, accounting for the 77 strains included in this comparison.

Table III shows the distribution of the various pyocine types of Pseudomonas aeruginosa according to the kinds of specimens from which the strains were isolated. "Patient strains" as defined for Table I were duplicated here when

TABLE II

Distribution of Patient Strains of Subtypes of Pyocine Type 1

\begin{tabular}{|c|c|c|c|c|c|c|c|c|c|c|c|c|c|c|}
\hline \multirow{2}{*}{$\begin{array}{c}\text { Hospital } \\
\text { areas }\end{array}$} & \multicolumn{13}{|c|}{ Subtypes of Pyocine Type 1} & \multirow[b]{2}{*}{ Total } \\
\hline & 1 & 2 & 3 & 4 & 5 & 6 & 7 & 8 & 9 & 10 & 11 & 12 & 13 & \\
\hline $\begin{array}{l}\text { Respiratory } \\
\text { failure unit } \\
\text { Ward A South } \\
\text { Other areas }\end{array}$ & $\begin{array}{l}0 \\
0 \\
3\end{array}$ & $\begin{array}{r}8 \\
2 \\
28\end{array}$ & $\begin{array}{r}0 \\
4 \\
22\end{array}$ & $\begin{array}{l}\mathbf{1} \\
1 \\
\mathbf{3}\end{array}$ & $\begin{array}{l}0 \\
0 \\
1\end{array}$ & $\begin{array}{l}1 \\
0 \\
4\end{array}$ & $\begin{array}{l}0 \\
0 \\
0\end{array}$ & $\begin{array}{r}1 \\
0 \\
10\end{array}$ & $\begin{array}{l}0 \\
0 \\
0\end{array}$ & $\begin{array}{l}0 \\
0 \\
3\end{array}$ & $\begin{array}{l}1 \\
0 \\
0\end{array}$ & $\begin{array}{l}0 \\
1 \\
1\end{array}$ & $\begin{array}{l}0 \\
0 \\
2\end{array}$ & $\begin{array}{r}13 \\
8 \\
77\end{array}$ \\
\hline Total & 3 & 38 & 26 & 5 & 1 & 5 & 0 & 11 & 1 & 3 & 1 & 2 & 2 & 98 \\
\hline
\end{tabular}


TABLE III

Results of Pyocine Typing of Patient Strains of Pseudomonas aeruginosa According to THE KINDS OF SPECIMENS FROM WHICH THE STRAINS WERE ISOLATED*

\begin{tabular}{|c|c|c|c|c|c|c|}
\hline \multirow[b]{2}{*}{ Kinds of specimen } & \multicolumn{3}{|c|}{ Pyocine type $(\%)$} & \multirow{2}{*}{$\begin{array}{c}\text { Other } \\
\text { types } \\
(\%)\end{array}$} & \multirow{2}{*}{$\begin{array}{c}\text { Non- } \\
\text { typable } \\
(\%)\end{array}$} & \multirow{2}{*}{$\begin{array}{c}\text { Total } \\
(\%)\end{array}$} \\
\hline & 1 & 10 & 3 & & & \\
\hline \multirow{2}{*}{$\begin{array}{l}\text { Sputum } \\
\text { Urine } \\
\text { Other (blood, ear, wounds, } \\
\quad \text { dialysate fluid, etc.) }\end{array}$} & $\begin{array}{l}28(33) \\
28(24)\end{array}$ & $\begin{array}{l}25(30) \\
20(17)\end{array}$ & $\begin{array}{l}7(8) \\
5(4)\end{array}$ & $\begin{array}{l}34(41) \\
35(29)\end{array}$ & $\begin{array}{r}7(8) \\
14(12)\end{array}$ & $\begin{array}{l}100(120) \\
100(86)\end{array}$ \\
\hline & $33(31)$ & $14(13)$ & $6(6)$ & $34(32)$ & $13(12)$ & $100 \quad(94)$ \\
\hline
\end{tabular}

*"Patient strains," as defined in Table I, are duplicated here when isolated from different kinds of specimens. Numbers of patient strains are shown in parentheses.

isolated from different kinds of specimens. The distribution of pyocine types according to the kinds of specimen is not significantly different.

\section{Discussron}

Several articles report isolations of Pseudomonas aeruginosa in increasing numbers and variously have suggested that this increase is due to, or associated with, broad spectrum antibiotics, immunosuppressive agents, severe disease, prolonged intubation, prolonged hospital stay, or contaminated equipment. ${ }^{\mathbf{5}, 6}$

There is little information about the primary source of these organisms. In normal individuals this species is seldom isolated from the respiratory tract ${ }^{7}$ or the intestine ${ }^{8}$ and is not so easily found in the environment as to suggest that there commonly exists a substantial reservoir. Specific instances of cross-infection by contaminated respiratory equipment ${ }^{9}$ are balanced by others where no obvious source could be determined. ${ }^{5}$ The most likely source of the organism is endogenous with colonization of the pharynx, and it probably spreads through the respiratory tract to the bronchi and lungs. The patients in the survey wards were expected to show a high colonization rate with Pseudomonas aeruginosa, since most were seriously ill., ${ }^{5,7}$

Untypable strains numbered 12.1 per cent, a figure agreeing well with the 10.6 per cent of Gillies and Govan. ${ }^{3}$ The predominance of Type 1 (28.6 per cent) was not a unique finding, since Govan and Gillies ${ }^{4}$ reported in a study of 2396 strains that 34.2 per cent were Type 1 .

Comparison of the types isolated from the combined respiratory wards with those from the general hospital population (Table I) does not show any significant difference in the proportions of the different types. The figure of 39.1 per cent of Type 10 from the respiratory failure unit is obtained from too small a population to be significantly different from the 15.5 per cent isolated from the general hospital population. Though this is likewise not statistically significant, it is tempting to interpret the pattern of occurrence of Subtype 2 in the respiratory failure unit as cross-infection. Of the eight strains of this subtype isolated, five were from patients whose periods of stay overlapped through a ten-day period (Table IV). 
TABLE IV

Admission and Discharge Dates

\begin{tabular}{lll}
\hline \hline Patient* & Date admitted & Date discharged \\
\hline M.G. & August 16 & August 30 (died) \\
W.B. & August 24 & September 8 \\
C.H. & August 30 & October 1 (died) \\
J.G. & September 1 & September 14 \\
M.K. & September 8 & September 22 \\
\hline
\end{tabular}

*These five patients were resident in the respiratory failure unit either concurrently or sequentially. Type 1 , Subtype 2 Pseudomonas aeruginosa was isolated from them.

The distribution of types isolated from different kinds of specimens is not significantly different. This finding agrees with that of Zabransky and Day. ${ }^{2}$

\section{SUMMARY}

Pyocine typing of patient strains of Pseudomonas aeruginosa has proved to be a useful epidemiological tool in a large general hospital to indicate that there does not appear to be an overall problem of hospital cross-infection (exogenous nosocomial infection) in those wards where intubation and use of inhalation therapy equipment are common. Instead, the observations of this study substantiate the findings of other workers that Pseudomonas aeruginosa infections (or colonizations) of the respiratory tract are more likely to be endogenous nosocomial in origin.

\section{RÉSUMÉ}

La pyocine typant des colonies de Pseudomonas aeruginosa chez les malades, s'est avérée un outil épidémiologique utile dans un grand hôpital général pour démontrer qu'il ne semble pas se poser un problème général d’infection croisée hospitalière (infection nosocomiale exogènée) dans les salles où l'on pratique, de façon courante, et la thérapie par inhalation et lintubation. Bien au contraire, les observations de cette étude confirment en quelque sorte les résultats des autres chercheurs, à savoir: que les infections à Pseudomonas aeruginosa ou colonizations des voies respiratoires sont, selon toute vraisemblance, d'origine nosocomiale endogène.

\section{ACKNowledgMENTS}

Indicator strains were gratefully received from the Department of Microbiology, Sunnybrook Hospital, Toronto. Statistical analysis was conducted in the Biometrics Department, Toronto General Hospital, by D. B. W. Reid and E. Kuzin. The encouraging interest of Dr. A. Scott was appreciated.

\section{REFERENCES}

1. Darfeli, J. H. \& Warria, A. H. Pyocine Typing of Hospital Strains of Pseudomonas pyocyanea. J. Clin. Pathol. 17: 236 (1964). 
2. Zabransky, R. J. \& Dax, F. E. Pyocine Typing of Clinical Strains of Pseudomonas aeruginosa. Appl. Microbiol. 17: 293 (1969).

3. Gillies, R. R. \& Govan, J. R. W. Typing of Pseudomonas pyocyanea by Pyocine Production. J. Pathol. Bact. 91: 339 (1966).

4. Govan, J. R. W. \& Gilles, R. R. Further Studies in the Pyocine Typing of Pseudomonas pyocyanea. J. Med. Microbiol. 2: 17 (1968).

5. REDMAN, L. R. \& LockeY, E. Colonization of the Upper Respiratory Tract. Anaesthesia. 22: 220 (1967).

6. LePper, M. H. Opportunistic Gram-negative Rod Pulmonary Infections. Dis. Chest. 44: $18(1963)$.

7. Johanson, W. G.; Pierce, A. K.; \& Sanford, J. P. Changing Pharyngeal Bacterial Flora of Hospitalized Patients: Emergence of Gram-negative Bacilli. New England J. Med. 281: 1137 (1969).

8. SUtTer, V. L.; HURST, V.; \& LANE, C. W. Quantification of Pseudomonas aeruginosa in Feces of Healthy Human Adults. Health Lab. Sc. 4: 245 (1967).

9. Phullips, IAN. Pseudomonas aeruginosa. Respiratory Tract Infections in Patients Receiving Mechanical Ventilation. J. Hyg. Camb. 65: 229 (1967). 